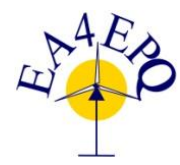

International Conference on Renewable Energies and Power Quality (ICREPQ'13) Bilbao (Spain), 20 $0^{\text {th }}$ to $22^{\text {th }}$ March, 2013

Renewable Energy and Pourer Qualim. Fournal (RE\&PQJ)

ISSN 2172-038 X, No.11, March 2013

\title{
Role of Policies on Economic Feasibility of PV Projects
}

\author{
M. H. Albadi, A. H. Al-Badi, A. S. Malik, A. M. Al-Lawati \\ Department of Electrical \& Computer Engineering \\ Sultan Qaboos University \\ Muscat-123, Sultanate of Oman
}

Tel: +968 24142664 , Fax: +96824413454

Email: mbadi@squ.edu.om, albadi@squ.edu.om, Lawati@squ.edu.om, asmalik@squ.edu.om

\begin{abstract}
This paper utilizes solar radiation data of 25 locations in Oman to investigate economic viability of PV projects considering different market conditions. The study investigates the effects of corporate income tax rate, capital cost allowance, and greenhouse gas reduction credit on the feasibility of a typical $5 \mathrm{MW}$ PV power plant at each of the 25 locations. The results show that despite the generous taxation rate in Oman, taxes represent a big burden on renewable energy projects investors; therefore could hinder investments in this sector when capital cost allowances are not considered in tax calculations
\end{abstract}

\section{Key words}

Renewable energy, Economic Feasibility, Cost of Energy, Renewable energy support policies.

\section{Introduction}

The Sultanate of Oman is located in southwest Asia on the extreme south-eastern corner of the Arabian Peninsula sharing its borders with three countries: the Republic of Yemen, the United Arab Emirates and the Kingdom of Saudi Arabia [1]. The total land area of the country is 309,500 square $\mathrm{km}$ with total population of about 3 million [2]. As Oman is thinly populated and geographically spread, the power systems in Oman are not fully interconnected. Most of the electrical power produced is based on natural gas. Moreover, the load in some remote rural areas is concentrated to small communities and therefore locally supplied by the diesel generators [3].

In this study, the effects of corporate income tax rate, capital cost allowance, and greenhouse gas reduction credit on the PV project's economic feasibility is investigated. Net present value (NPV) of the project at different sites is used as economic feasibility indicator.

After this introduction, the paper proceeds with presenting system data that includes the characteristics of PV system under study, the captured renewable energy at different locations, as well as the economic and other parameters considered in the study. In Section Three, taxation policies in Oman as well as the list of different policy scenarios are presented. The results and
Although Oman is located in a region where solar energy potential is excellent, solar energy applications have been mainly limited to street lighting, traffic lights, telephone services in remote areas, and cathodic protection of pipelines. In the past there has been little funding provided for research and development for the growth of the Omani renewable energy sector. However, such reservations on renewable energies in this oil and gas producing country has changed into a realization that renewable resources are essential components of its national energy supplies, as well as a global strategic option for both extending the life of oil and gas reserves and reducing carbon dioxide emissions and thus combating climate change. The Government has recently taken some initiatives in this direction.

The Authority for Electricity Regulation in Oman has confirmed a shortlist of six renewable energy pilot projects four of them are solar projects [4]. The six shortlisted projects offer $6.6 \mathrm{MW}$ of renewable capacity at an investment cost of some 8.1 million Omani Rials (1 OMR = US\$2.58) [4]. The six shortlisted projects, if implemented, would allow Rural Areas Electricity Company (RAECO) to replace $11 \mathrm{GWh}$ of annual diesel generation with renewable sourced electricity, this would reduce diesel fuel consumption by 3.1 million liters per year and avoid 8,298 metric tons of $\mathrm{CO} 2$ per year [4].

Several studies on solar and wind energy resource assessment in Oman were published. Article [5] is one the most recent studies reported on solar energy in Oman. Utilizing solar radiation data of 25 locations in Oman, RETScreen software was used to study the economic prospects of solar energy considering a solar PV power discussions are presented in section Four. Finally, a summary of the main conclusions are presented.

\section{System Data}

A. PV System

The PV system consists of many PV arrays that are connected in parallel or series and then connected to the grid through an inverter. The PV arrays consist of PV modules which in turn are composed of several PV cells connected in parallel or series to produce a specific current and voltage in order to meet certain electrical requirements. 
In this study, a $150 \mathrm{~W}$ peak PV Module, which comprises mono-Si solar cells from Apin Solar [6], is considered as shown in Table I. The study assumes a PV power plant of $5 \mathrm{MW}$ installed capacity comprised of 33,334 modules. The total solar collector area required for the $5 \mathrm{MW}$ is $42,736 \mathrm{~m} 2$ [7]. Due to the effect of temperature and dirt; the plant is not expected to produce its rated output. Therefore, a 4.75 MW inverter size is selected. No tracking system is considered and the PV modules are assumed to be inclined at an angle equal to the site latitude and south facing [7].

Table I. Photovoltaic Module Specifications

\begin{tabular}{|l|l|}
\hline Item & Specifications \\
\hline Maximum power & $150 \mathrm{~W}$ \\
\hline Module efficiency & $11.7 \%$ \\
\hline Open circuit voltage & $41.8 \mathrm{~V}$ \\
\hline Short circuit current & $5,05 \mathrm{~A}$ \\
\hline Width & $1250 \mathrm{~mm}$ \\
\hline Length & $1250 \mathrm{~mm}$ \\
\hline Thickness & $35 \mathrm{~mm}$ \\
\hline Weight & $15.5 \mathrm{~kg}$ \\
\hline
\end{tabular}

\section{B. Captured Solar Energy}

The global solar radiation data for 25 locations in Oman are used as in [5]. Given the global solar irradiation at a certain site, the RETScreen model computes the radiation on a tilted PV array based on the algorithm described in [8]. Since the module efficiency is given at a certain reference temperature, the RETScreen PV energy model corrects the delivered energy for the site ambient temperature [7]. In addition, 5\% miscellaneous losses are considered to account for losses due to the presence of dirt on the PV modules [7]. Moreover, part of the captured solar energy is lost in the inverter. In this study, $90 \%$ inverter efficiency is presumed [7, 9]. Having the net energy output of the PV system, Capacity Factor (CF) value can be calculated as shown in Table II [5]. As the value of $\mathrm{CF}$ represents the ratio of the average power produced by the power station over a year to its rated power, it can be used to rank candidate project sites.

Table II. Capacity Factor Values for Different Locations

\begin{tabular}{|c|c|c|c|}
\hline Location & $\mathbf{C F}$ & Location & $\mathrm{CF}$ \\
\hline Marmul & $20.56 \%$ & Nizwa & $17.78 \%$ \\
\hline Sohar & $18.92 \%$ & Ibra & $17.78 \%$ \\
\hline Fahud & $18.46 \%$ & Samail & $17.78 \%$ \\
\hline Diba & $18.37 \%$ & Rustaq & $17.77 \%$ \\
\hline Khasab & $18.20 \%$ & Bahla & $17.77 \%$ \\
\hline Qairoon Hairiti & $18.19 \%$ & Rusayl & $17.75 \%$ \\
\hline Yalooni & $18.16 \%$ & Martah & $17.38 \%$ \\
\hline Umm Zamaim & $18.06 \%$ & $\begin{array}{l}\text { Sultan Qaboos } \\
\text { Port }\end{array}$ & $17.25 \%$ \\
\hline Thumrait & $17.95 \%$ & Masirah & $16.20 \%$ \\
\hline Buraimi & $17.91 \%$ & Port of Salalah & $15.55 \%$ \\
\hline Seeb & $17.85 \%$ & Salalah & $15.45 \%$ \\
\hline Adam & $17.84 \%$ & Sur & $14.26 \%$ \\
\hline Saiq & $17.80 \%$ & & \\
\hline
\end{tabular}

Table III shows the cost of the main components of the PV power plant, obtained from literature $[5,7,10]$.
About two thirds of the total cost accounts for purchasing, transportation and installation of PV panels. In this analysis, the project life is considered 25 years as in [5].

A debt ratio of $50 \%$ and a loan term of 10 years on a $5.5 \%$ interest rate are considered. Having an equity rate of $8.5 \%$, the weighted average cost of capital (discount rate) is $7.5 \%$ similar to that considered by the Authority for Electricity Regulation in Oman [9].

Table III. Cost and Economic Assumptions of the PV Plant

\begin{tabular}{|c|c|c|}
\hline Item description & Cost (US\$) & $\begin{array}{l}\% \text { of total } \\
\text { cost }\end{array}$ \\
\hline Feasibility study & 80,000 & $0.5 \%$ \\
\hline Development & 70,000 & $0.5 \%$ \\
\hline Engineering & 60,000 & $0.4 \%$ \\
\hline Photovoltaic & $10,020,000$ & $65.6 \%$ \\
\hline Inverter & $3,567,250$ & $23.4 \%$ \\
\hline $\begin{array}{l}\text { Balance of system \& } \\
\text { miscellaneous }\end{array}$ & $1,478,780$ & $9.6 \%$ \\
\hline $\begin{array}{l}\text { Total initial cost of PV } \\
\text { plant }\end{array}$ & $15,256,230$ & $100.0 \%$ \\
\hline $\begin{array}{l}\text { Inverter replacement } \\
\text { cost }\end{array}$ & $2,000,000$ & $\begin{array}{l}\text { Every } 10 \\
\text { years }\end{array}$ \\
\hline Annual O\&M & 300,000 & \\
\hline Debt/Equity ratio & $50 \%$ & \\
\hline Cost of Equity & $8.5 \%$ & \\
\hline Debt interest rate & $5.5 \%$ & \\
\hline Debt term & 10 years & \\
\hline Discount rate & $7.5 \%$ & \\
\hline Project life & 25 years & \\
\hline FIT rate & $\$ 300 / \mathrm{MWh}$ & \\
\hline
\end{tabular}

One of the most suitable policies for introducing renewable energy technologies to the market is Feed-inTariff (FIT) mechanism. According to this mechanism, eligible renewable power producers are paid a regulated feed-in tariff for a guaranteed period of time [5]. According to [11], the FIT has proved to be the most effective policy in promoting investments in renewable energy, because it reduces regulatory and market risks. Therefore, FIT system is widespread in many countries [12]. As an example, according to the current FIT policy for PV projects in Ontario, investors are paid a guaranteed price between 443 and $802 \mathrm{CAN} \$ / \mathrm{MWh}$ for 20 years depending of the project size and whether it is rooftop or ground-mounted [13]. In this study, an FIT rate of US\$300/MWh is considered over the project lifetime.

\section{GHG Reduction Data}

As the PV project does not use fossil fuel to generate electricity, it has zero greenhouse gas (GHG) emissions. Energy from the PV system would replace a part of fossil fuels that is combusted in the generation plants; therefore, the captured solar energy will result in a reduction of $\mathrm{CO}_{2}$ emissions. In Oman, all power stations are using natural gas to generate electricity. In this analysis, a GHG emission factor of $0.660 \mathrm{tCO}_{2} / \mathrm{MWh}$ is considered. This value is calculated based on the default emission factor, provided by UN's Intergovernmental Panel on Climate Change (IPCC) [14], and an average efficiency of $34 \%$ [9]. 


\section{E. Policies}

\section{Taxation Policies in Oman}

According to the new corporate income tax legislation issued by royal decree 28/2009 that replaced the previous legislation originally issued in 1981 by royal decree $47 / 1981$, the highest corporate tax rate for companies is $12 \%$ expect oil companies for which $55 \%$ tax rate is applicable [15]. Therefore, in this study, the $12 \%$ corporate income tax rate is considered.

\section{Capital Cost Allowance}

Normally, capital intensive projects are promoted through tax write-off programs, such as Capital Cost Allowance (CCA) programs. In these programs, taxpayers are allowed to deduct the cost of eligible equipment (e.g., PV system) at a certain rate depending on depreciation method.

According to the new tax legislation, depreciation of capital assets can be calculated using two methods: the straight-line method and the declining balance method. A $33.3 \%$ Accelerated Declining Balance (ADB) rate is to be applied for heavy machinery, computers and software, $10 \%$ for drilling rigs, and $15 \%$ for any other items that does not fall within the previous two categories. Therefore, in this analysis, $15 \%$ ADB is considered [15].

In fact, the ADB method is typically used to promote investments in renewable projects that have high capital cost requirements and long lifetime. Using ADB depreciation method delays tax payment compared to using straight line method. Due to time value of money, the ADB method is better from tax payers' perspective [16].

\section{GHG Reduction Credit Income}

The RETScreen PV model allows the user to enter the GHG reduction credit per equivalent ton of $\mathrm{CO}_{2}$ $\left(\mathrm{tCO}_{2}\right)$. The annual GHG reduction income for a renewable energy project is calculated using the Prices for $\mathrm{tCO}_{2}$ reduction credits. Prices for $\mathrm{CO}_{2}$ reduction credits differ based on many factors such as how the credit is generated and how it will be delivered. Additionally, this value is influenced by whether the emissions reduction is voluntary or mandatory; the purchase of credits is private or public; the GHG trading scheme as well as the type of technology used [7]. In this study, $\$ 20 / \mathrm{tCO}_{2}$ is considered as in $[5,9]$.

\section{List of Scenarios}

To investigate the effect of policies on the economic feasibility of PV projects, six combinations of policies are considered as listed below:

Scenario\#1:In this scenario, $12 \%$ corporate taxation rate is applied without considering CCA. No GHG Credit policy is assumed.

Scenario\#2: In this scenario, $12 \%$ corporate taxation rate is applied without considering CCA. A \$20/tCO2 GHG Credit policy is assumed.

Scenario\#3: In this scenario, $12 \%$ corporate taxation rate is applied while considering CCA on $15 \%$ ADB basis. No GHG Credit policy is assumed.
Scenario\#4: This scenario considers pre-tax analysis and no GHG Credit policy.

Scenario\#5: In this scenario, $12 \%$ corporate taxation rate is applied while considering CCA on $15 \%$ ADB basis. A $\$ 20 / \mathrm{tCO} 2$ GHG Credit policy is assumed.

Scenario\#6: This scenario considers pre-tax analysis and a $\$ 20 / \mathrm{tCO} 2$ GHG Credit policy.

\section{Results and Discussions:}

In this section, impact of different policies on the PV project's economic feasibility is studied using Net Present Value (NPV) as the economic feasibility indicator.

Due to the time value of money, a hundred dollars today are more valuable than a hundred dollars in the future. The Net Present Value (NPV) approach uses the time value of money to convert future cash flow into a present value at a certain discount rate [7]. The NPV of a project is the difference between revenues and costs in today's money. In any comparison of investing options, the project with the maximum NPV is the winning one.

The project's NPV for different scenarios and locations is calculated as shown in Fig. 1. The results demonstrate that for the same policy, the higher the CF of the project is, the higher its NPV. For Sur, which has the lowest CF value, the NPV is negative or close to zero for some scenarios.

By comparing scenarios 1 and 4 (GHG credit excluded), the results demonstrate the effect of taxation on the economic feasibility of the project. Despite the generous taxation rate, taxes would reduce the NPV of the project in Marmul from US\$10.16 Million to US\$ 7.33 Million (28\% reduction) when CCA is not considered. For Sur location, the project's NPV with scenario 4 is US\$0.93 Million compared to -US\$0.83 Million with scenario 1. This means that taxation could make the investment infeasible in some locations when CCA is not included in tax calculations. Similar tentative conclusions about the effect of taxation on the NPV of the project can be observed by comparing scenarios 2 and 6 (GHG included)

However, the effect of taxation can be substantially reduced when CCA is considered. By comparing the project's NPV of scenarios 1 and 3 for Sur, it is clear that the project becomes feasible with an NPV of US\$0.22 Million. For the most attractive site (Marmul), including CCA would improve project's NPV to US\$ 8.43 Million, a $15 \%$ increase compared with scenario 1. Similar tentative conclusions about the effect of CCA on the project's feasibility can be observed by comparing scenarios 2 and 5 (GHG included). The effect of GHG reduction income on the project's NPV can be observed by comparing scenarios 1 and 2 (CCA excluded), scenarios 3 and 5 (CCA included) or scenarios 4 and 6 (taxes excluded). The results demonstrate the positive impact of the GHG credit on the NPV of the project. For Marmul site, the difference between scenarios 1 and 2, scenarios 3 and 5 and scenarios 4 and 6 is US\$1.17, US\$1.17 and US\$1.33 Million, respectively. For the same scenario, the increase in GHG reduction income increases as with the $\mathrm{CF}$ values. 


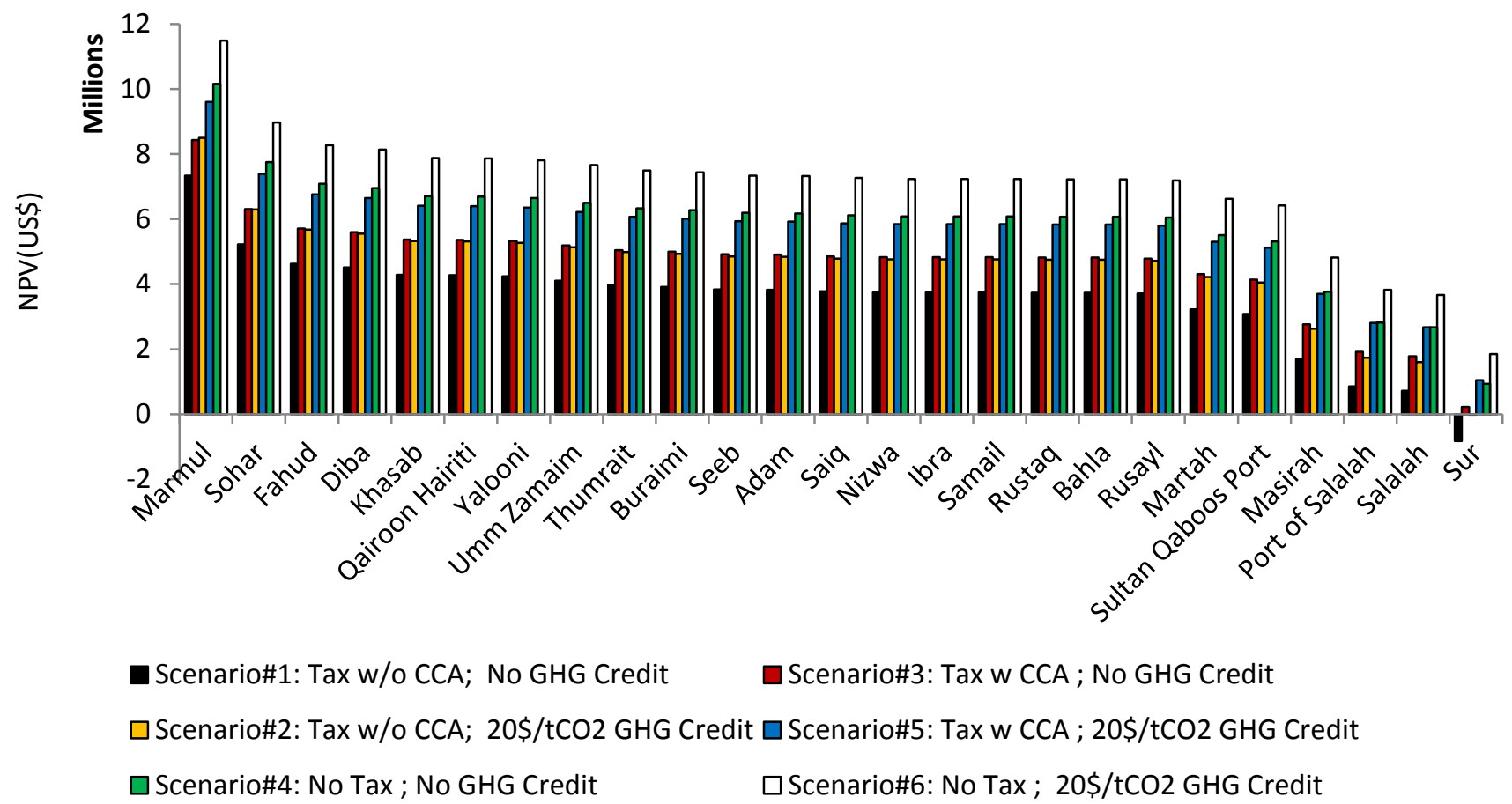

Fig.1 Impacts of different policies on the NPV for different locations in Oman

\section{Conclusions}

Global solar radiation data of 25 locations in Oman were used to study the economic viability of PV projects considering different market conditions. The study assumed a solar PV power plant of 5-MW at each of the 25 locations and investigated the effects of corporate income tax rate, capital cost allowance, and greenhouse gas reduction credit on each location. The results show that despite the generous corporate tax rate in Oman, taxes represent a big burden on renewable energy projects investors; therefore could hinder investments in this sector if capital cost allowances are not considered in tax calculations. Due to high initial cost requirements of renewable energy projects, capital cost allowances reduce taxes and improve the project economic feasibility significantly.

\section{References}

[1] UN Cartographic Section. Map of Oman. January 2004, No. 3730 Rev. http://www.unhcr.org/refworld/docid/460a393b2.html, accessed 26th August, 2012.

[2] Ministry of National Economy. $\mathrm{http} / / /$ www.moneoman.gov.om. accessed 26th August, 2012.

[3] Oman Power and Water Procurement Company. 7-Year Statement (2010 - 2016). Dec. 2009.

[4] The Authority for Electricity Regulation Oman. press release. 5 April 2010. http://www.aeroman.org/index.php?option=com_content $\&$ view $=$ article\&id $=146$, accessed 26th August, $201 \overline{2}$.

[5] A. H. Al-Badi, M. H. Albadi, A. M. Al-Lawati and A. S. Malik, "Economic Perspective for PV Electricity in Oman," Energy-The International Journal, Vol. 36, No. 1, pp. 226232, January 2011.

[6] Sinopuren Energy Group Ltd. http://www.sinopuren.com., accessed 26th August, 2012.
[7] RETScreen, International renewable energy project analysis software. http://www.retscreen.net, accessed 26th August, 2012.

[8] Duffi J A, Beckman W A. Solar Engineering of Thermal Processes. 2nd ed. John Wiley \& Sons; 1991.

[9] Authority for Electricity Regulation - Oman, Study on renewable Energy resources in Oman - Final Report, Muscat, May 2008.

[10] Solarbuzz, a division of The NPD Group, http://www.solarbuzz.com, accessed 26th August, 2012.

[11] Sawin J, Flavin C. National policy Instruments: Policy lessons for the advancement and diffusion of renewable energy technologies around the world - Thematic Background Paper. in The International Conference for Renewable Energies. Bonn, Germany, 2004.

[12] European Wind Energy Association (EWEA). Wind Energy The Facts: A Guide to the Technology, Economics and Future of Wind Power. London: Earthscan Publications Ltd., 2009.

[13] Info on Ontario's new PV Feed In Tariff (FIT) program, www.OntarioPV.com, accessed 9th July, 2011.

[14] Intergovernmental Panel on Climate Change (IPCC), 2006 IPCC Guidelines for National Greenhouse Gas Inventories, Prepared by the National Greenhouse Gas Inventories Programme, Eggleston H.S., Buendia L., Miwa K., Ngara T. and Tanabe K. (eds), IGES, Japan, 2006.

[15] Royal Decree 28/2009, Ministry of Legal Affairs, http://www.mola.gov.om/maraseem/888/28-2009.pdf, accessed 26th August, 2012.

[16] M. H. Albadi, E. F. El-Saadany and H. A. Albadi, "Wind to power a new city in oman," Energy-The International Journal, Vol. 34, No. 10, pp. 1579-1586, October 2009. 